\title{
Development of Real-Time RT-PCR Assay for Detection of Prunus necrotic ringspot virus in Fruit Trees
}

\author{
S. Marbot, M. Salmon, M. Vendrame, A. Huwaert, J. Kummert, O. Dutrecq, and P. Lepoivre, Unité de \\ Phytopathologie, Faculté Universitaire des Sciences Agronomiques de Gembloux (FUSAGx), Passage des Déportés \\ 2, B-5030 Gembloux, Belgium
}

\begin{abstract}
Marbot, S., Salmon, M., Vendrame, M., Huwaert, A., Kummert, J., Dutrecq, O., and Lepoivre, P. 2003. Development of real-time RT-PCR assay for detection of Prunus necrotic ringspot virus in fruit trees. Plant Dis. 87:1344-1348.

A real-time fluorescent reverse-transcriptase polymerase chain reaction (RT-PCR) assay using a short fluorogenic $3^{\prime}$ minor groove binder (MGB) DNA hydrolysis probe was developed for the detection of Prunus necrotic ringspot virus (PNRSV) in stone fruit trees. The covalent attachment of the minor groove binder moiety at the $3^{\prime}$ end of the probe increased the probe target duplex stability and raised the melting temperature to a range suitable for real-time analysis. The real-time RT-PCR assay correlated well with conventional RT-PCR results for the detection of PNRSV. This assay reliably detects PNRSV in bark tissues of dormant cherry and plum trees. Furthermore, it is well adapted for the routine detection of PNRSV because it eliminates one risk of contamination by performing the whole test in a single closed tube. This system may replace the commonly used diagnostic techniques (e.g., woody indicators and immunological tests) to detect this virus.
\end{abstract}

Additional keywords: phytosanitary certification, RNA preparations

Prunus necrotic ringspot virus (PNRSV) causes fruit yield losses (25) and affects fruit maturity or tree growth of many commercial Prunus spp. (e.g., peach, plum, apricot, sweet cherry, and almond) (16). Consequently, this virus is a component of many phytosanitary certification programs for fruit trees. It produces many symptoms according to the cultivars; sometimes infected plants are asymptomatic $(9,21,26)$. PNRSV belongs to the genus Ilarvirus (isometric labile ringspot viruses) (5) and includes many strains that differ in pathogenicity (9), biophysical (3) and serological properties $(3,23)$, and restriction fragment length polymorphism profiles (23). PNRSV is graft and pollen-transmitted and potentially seedborne (25). These properties contribute to its rapid spread in stone fruit trees and its worldwide distribution. The detection of PNRSV in fruit trees tissues is problematic because virus concentration fluctuates between seasons and the virus is unevenly distributed in infected trees $(21,24)$.

Corresponding author: P. Lepoivre

E-mail: lepoivre.p@fsagx.ac.be

This work was supported by the General Directorate for Technologies, Research and Energy of the Wallonia Region, Belgium (DGTRE), in the framework of the research agreement $\mathrm{N}^{\circ} 001 / 4542$.

Accepted for publication 16 June 2003.

Publication no. D-2003-0909-02R

(C) 2003 The American Phytopathological Society
Reliable detection of PNRSV is required in phytosanitary certification programs. Serological methods, such as enzymelinked immunosorbent assay (ELISA) (2), often are not sensitive enough for detection of PNRSV in dormant woody material sampled in winter (22). Reverse-transcriptase polymerase chain reaction (RTPCR) methods can surpass ELISA in sensitivity for PNRSV detection in dormant fruit trees $(18,22)$. However, these methods require a post-amplification detection of PCR products by agarose gel electrophoresis. These post-amplification manipulations increase the risk of carryover between wells and contamination that subsequently can lead to misdiagnosis in routine use.

The real-time detection of specific amplification products using hydrolysis probes is particularly useful because it eliminates the need for post-PCR processing steps $(10,17,27)$. The fluorogenic 5' nuclease assays (TaqMan; PE-Biosystems, Foster City, CA; 1,8,13,14) are based on the real-time measurement of fluorescence resulting from the hydrolysis of a fluorescent probe (TaqMan probe) that hybridizes specifically to the target PCR product during amplification. This molecular detection method is very fast, highly sensitive, and occurs within a single tube.

We describe the development and validation of a real-time RT-PCR assay that allows the reliable detection of PNRSV in bark tissues of dormant wood. This assay is appropriate for routine PNRSV-testing protocols.

\section{MATERIALS AND METHODS}

Plant material. Twigs of PNRSV-infected GF 305 peach seedlings were kindly provided by B. Pradier (Station de Quarantaine des Ligneux, Lempdes, France), R. Guillem (Laboratoire National de la Protection des Végétaux, Villenave d'Ornon, France), and T. Candresse (Institut National de la Recherche Agronomique, Villenave d'Ornon, France). These materials were obtained by chip budding on GF 305 seedlings grown under greenhouse conditions. The PNRSV isolates originated from various geographic regions and from different species of fruit trees and rose (Table 1). Bark tissues were collected on various parts of two twigs per seedling to minimize effects of uneven virus distribution.

Orchard trees (plum and cherry) from the collections of the Faculté Universitaire des Sciences Agronomiques de Gembloux (FUSAGx), Belgium, and the Centre de Recherche Agronomique de Gembloux (CRAGx), Belgium, also were tested. It was not known with certainty if these trees were infected with PNRSV or not. Two 1year-old branches per tree were collected and processed twice during the year: in winter (5 February 2002) and in spring (24 April 2002). Forty-one trees were tested in winter and in spring, and nine additional trees were tested only in spring. Bark tissues were removed from these branches immediately after harvest. Total nucleic acid then was extracted from these bark samples.

Total nucleic acid extraction. Total nucleic acids were extracted from $0.4 \mathrm{~g}$ of bark tissue, according to the method described by Spiegel et al. (22). The total nucleic acid concentrations and extraction purities were estimated after determining the absorbance at 260 and $280 \mathrm{~nm}$ with a spectrophotometer (LKB Biochrom Ultrospec II, UK).

Primer design. Specific primers for PNRSV were identified by computer analysis using the PILEUP, FASTA, and PRIME programs (Wisconsin Package version 10.1; Genetic Computer Group, Madison, WI). These programs were applied to sequence data corresponding to the virus coat protein $(\mathrm{CP})$-encoding sequence of PNRSV-RNA 4, from 24 isolates available in the GenBank database of National Center for Biotechnology Information and at the European Molecular Biology Laboratory databases (11). Among the potential 
primer pairs identified, the primers PNRSV 10F (TTC TTG AAG GAC CAA CCG AGA GG) and PNRSV 10R (GCT AAC GCA GGT AAG ATT TCC AAG C), amplifying a fragment of $348 \mathrm{bp}$, were selected. Synthesis and purification of the primers were performed by Eurogentec (Seraing, Belgium).

$3^{\prime}$ minor groove binder probe design. The $3^{\prime}$ minor groove binder (MGB) DNA probe was selected as described by Livak et al. (15), on the basis of 24 sequences aligned using the PILEUP program. The software Primer Express 5.1 (Applied Biosystems, Foster City, CA) was used for accurate calculation of the melting temperature. The probe was designed within a conserved region of the genome corresponding to the PNRSV 10F-10R amplification product based on available information. The probe containing the VIC reporter dye, covalently attached at the $5^{\prime}$ end, and a nonfluorescent quencher and the MGB moiety at the $3^{\prime}$ end $\left(5^{\prime}\right.$ [VIC] ATG TCT TGC TGG TCG ATG 3' [NFQ]) was supplied by Applied Biosystems.

RT-PCR assay. Amplification of $R T$ PCR products. RT-PCR was performed on the total nucleic acid preparations obtained from all the plant material by the OneStep RT-PCR Kit from Qiagen (Hilden, Germany). Reaction mixtures (total volume 25 $\mu \mathrm{l}$ ) contained total RNA (200 to $400 \mathrm{ng}$ ), $0.6 \mu \mathrm{M}$ of both primers PNRSV $10 \mathrm{~F}$ and PNRSV 10R, $0.2 \mu \mathrm{M}$ of the MGB probe, and the reagents from the kit $(5 \times$ buffer, dNTP mix, RNase-free water, Enzyme Mix). The GeneAmp 5700 Sequence Detection System (Applied Biosystems) was used for thermal cycling. The RT-PCR profile consisted of cDNA synthesis (30 min at $50^{\circ} \mathrm{C}$ ), activation of the HotStart Taq polymerase $\left(15 \mathrm{~min}\right.$ at $\left.95^{\circ} \mathrm{C}\right)$, and 40 amplification cycles $\left(15 \mathrm{~s}\right.$ at $95^{\circ} \mathrm{C}, 45 \mathrm{~s}$ at $55^{\circ} \mathrm{C}$, and $1 \mathrm{~min}$ at $60^{\circ} \mathrm{C}$ ). The cycle number was increased to 50 to confirm the results of some assays.

Analysis of amplified RT-PCR products. Analysis of all amplified RT-PCR products was carried out both by recording fluorescence (real-time RT-PCR) and by gel electrophoretic analysis (conventional RTPCR). For the real-time detection, the GeneAmp 5700 Sequence Detection System was used to record fluorescence at the extension step of each amplification cycle. The threshold cycle $(\mathrm{Ct})$ is the cycle at which a significant increase in fluorescence occurs. The $\mathrm{Ct}$ values were calculated using the 5700 SDS software. According to the recommendations of Applied Biosystems, the threshold of the fluorescence emission was calculated as a value which is 10 times the standard deviation above the mean fluorescence generated during the baseline cycles (from cycles 3 to 15).

Aliquots $(8 \mu \mathrm{l})$ of amplified products were electrophoresed in ethidium bromide stained agarose gel (1\%), in 1× TAE buffer (Tris-acetate at $40 \mathrm{mM} /$ liter, EDTA at 1 $\mathrm{mM} /$ liter, $\mathrm{pH}$ 8.0).

To ensure the absence of contamination, each RT-PCR run included a water control. Total RNA preparations of a virus-free cherry tree, which had been tested periodically by RT-PCR using the same primers during the preceding 2 years, were included as healthy controls in each RT-PCR run. All RT-PCR experiments were repeated three times with

Table 1. Detection of Prunus necrotic ringspot virus (PNRSV) from peach twigs ${ }^{\mathrm{a}}$

\begin{tabular}{|c|c|c|c|c|}
\hline Isolate no. ${ }^{\mathbf{b}}$ & Original host & Origin & Gel & Threshold cycle \\
\hline 1 & ? & France & + & 22 \\
\hline 2 & Almond & France (Auvergne) & + & 18 \\
\hline 3 & Plum & France (Franche Comté) & + & 20 \\
\hline 4 & Plum & France (PACA) & + & 19 \\
\hline 5 & Apricot & New Zealand & + & 18 \\
\hline 6 & Cherry & New Zealand & + & 21 \\
\hline 7 & Plum & France (Lorraine) & + & 24 \\
\hline 8 & Plum & France (Lorraine) & + & 24 \\
\hline 9 & Plum & France (Lorraine) & + & 23 \\
\hline 10 & Plum & France (Lorraine) & + & 24 \\
\hline 11 & Plum & France (Lorraine) & + & 37 \\
\hline 12 & Apricot & Italy & + & 20 \\
\hline 13 & Rose & France & + & 25 \\
\hline 14 & ? & $?$ & + & 23 \\
\hline 15 & Rose & Israel & + & 20 \\
\hline 16 & Rose & France & + & 19 \\
\hline 17 & Cherry & Germany & + & 21 \\
\hline 18 & $?$ & $?$ & + & 19 \\
\hline 19 & Plum & France & + & 19 \\
\hline 20 & Plum & France & + & 24 \\
\hline 21 & Rose & France & + & 22 \\
\hline 22 & Plum & Italy & + & 23 \\
\hline 23 & $?$ & $?$ & + & 21 \\
\hline 24 & Plum & Albania & + & 20 \\
\hline 25 & Cherry & USA & + & 18 \\
\hline 26 & Cherry & Germany & + & 20 \\
\hline 27 & Almond & Italy & + & 20 \\
\hline 28 & $?$ & $?$ & + & 18 \\
\hline 29 & Rose & France & + & 23 \\
\hline 30 & Rose & France & + & 23 \\
\hline 31 & Cherry & Germany & + & 26 \\
\hline 32 & Apricot & Italy & + & 23 \\
\hline Water & $\ldots$ & $\ldots$ & - & ND \\
\hline Healthy & $\ldots$ & $\ldots$ & - & ND \\
\hline
\end{tabular}

a Detection by agarose gel electrophoresis and in real-time of amplified products corresponding to PNRSV isolates in total plant RNA extracts from bark tissues of twigs of PNRSV-infected GF 305 seedlings. The table summarizes data from real-time detection and gel analysis; + and - indicate presence and absence, respectively, of the expected band on gel; ND = not detected (no fluorescence above the threshold at the end of the amplification reaction).

${ }^{\mathrm{b}}$ Water $=$ water negative control and Healthy $=$ healthy tree negative control.

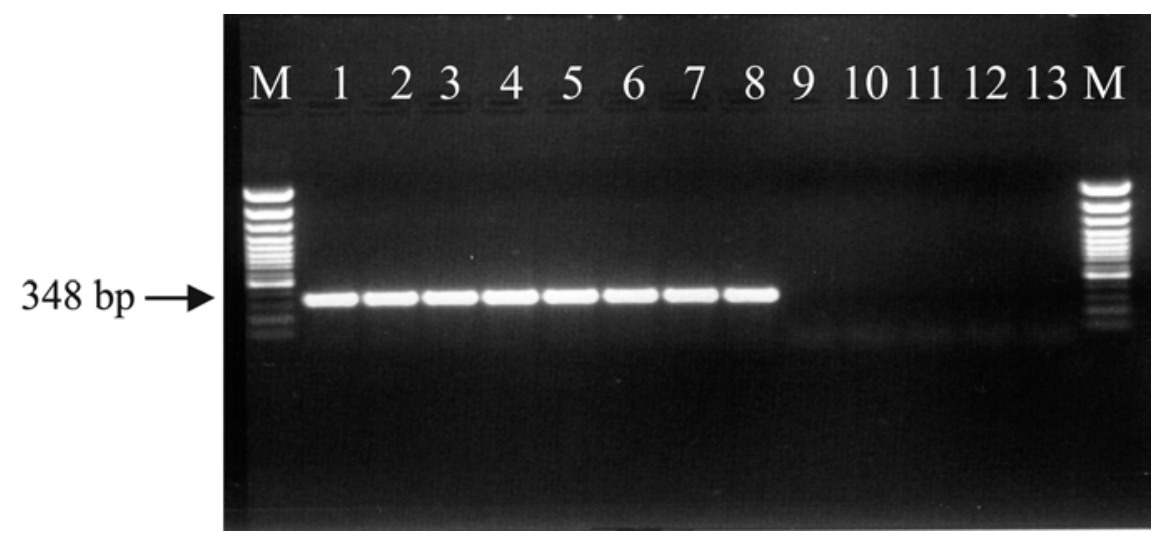

Fig. 1. Agarose gel analysis of reverse-transcriptase polymerase chain reaction (RT-PCR) assays. Lanes 1-8: RT-PCR products of total nucleic acid extracts of GF 305 peach twigs infected by standard Prunus necrotic ringspot virus (PNRSV) isolates (no. 1, 2, 3, 4, 5, 6, 7, and 8). Lanes 9-10: RTPCR products of total nucleic acid extracts of GF 305 peach twigs infected by standard Prune dwarf virus isolates. Lane 11: RT-PCR products of total nucleic acid extracts of GF 305 peach twigs infected by Apple mosaic virus standard isolate. Lane 12: RT-PCR products of total nucleic acid extracts of healthy tree. Lane 13: water control. M: 100-bp DNA ladder (GibcoBRL). 
reproducible results. The $\mathrm{Ct}$ given in each table is the mean of the three separate experiments.

\section{RESULTS}

Detection of PNRSV by conventional RT-PCR. RT-PCR specificity. A specific (348-bp) product was observed for all

Table 2. Detection of Prunus necrotic ringspot virus (PNRSV) from orchard trees in winter ${ }^{\mathrm{a}}$

\begin{tabular}{|c|c|c|c|}
\hline $\begin{array}{l}\text { Tree } \\
\text { number }\end{array}$ & Nature & Gel & $\begin{array}{c}\text { Threshold } \\
\text { cycle }\end{array}$ \\
\hline 1 & Cherry & + & 23 \\
\hline 2 & Cherry & + & 37 \\
\hline 3 & Cherry & + & 36 \\
\hline 4 & Cherry & - & ND \\
\hline 5 & Cherry & - & 39 \\
\hline 6 & Cherry & - & ND \\
\hline 7 & Cherry & - & ND \\
\hline 8 & Cherry & NT & NT \\
\hline 9 & Cherry & - & ND \\
\hline 10 & Cherry & + & 20 \\
\hline 11 & Cherry & - & 36 \\
\hline 12 & Cherry & + & 21 \\
\hline 13 & Plum & - & ND \\
\hline 14 & Cherry & - & ND \\
\hline 15 & Cherry & + & 39 \\
\hline 16 & Cherry & + & 36 \\
\hline 17 & Plum & - & 38 \\
\hline 18 & Plum & + & 34 \\
\hline 19 & Plum & + & 33 \\
\hline 20 & Cherry & + & 21 \\
\hline 21 & Cherry & + & 19 \\
\hline 22 & Cherry & + & 20 \\
\hline 23 & Cherry & NT & NT \\
\hline 24 & Cherry & + & 20 \\
\hline 25 & Cherry & + & 20 \\
\hline 26 & Cherry & + & 37 \\
\hline 27 & Cherry & + & 20 \\
\hline 28 & Cherry & + & 19 \\
\hline 29 & Cherry & - & ND \\
\hline 30 & Plum & + & 31 \\
\hline 31 & Cherry & NT & NT \\
\hline 32 & Cherry & + & 20 \\
\hline 33 & Cherry & + & 16 \\
\hline 34 & Cherry & + & 18 \\
\hline 35 & Cherry & NT & NT \\
\hline 36 & Cherry & + & 16 \\
\hline 37 & Cherry & + & 33 \\
\hline 38 & Plum & NT & NT \\
\hline 39 & Cherry & + & 20 \\
\hline 40 & Cherry & + & 20 \\
\hline 41 & Plum & NT & NT \\
\hline 42 & Plum & NT & NT \\
\hline 43 & Plum & NT & NT \\
\hline 44 & Plum & NT & NT \\
\hline 45 & Cherry & + & 37 \\
\hline 46 & Cherry & + & 33 \\
\hline 47 & Cherry & + & 33 \\
\hline 48 & Cherry & + & 37 \\
\hline 49 & Cherry & + & 37 \\
\hline 50 & Cherry & + & 37 \\
\hline Water & $\ldots$ & - & ND \\
\hline Healthy & $\ldots$ & - & ND \\
\hline
\end{tabular}

a Detection by agarose gel electrophoresis and in real-time of amplified products corresponding to PNRSV isolates in total RNA extracts from infected trees. The table summarizes data from real-time detection and gel analysis; + and - indicate presence and absence of the expected band on gel respectively; $\mathrm{NT}=$ not tested; ND = not detected.

${ }^{\mathrm{b}}$ Water $=$ water negative control and Healthy $=$ healthy tree negative control.
PNRSV isolates tested. The specificity of amplification was indicated by the absence of amplification products from tissues infected with other closely related ilarviruses (e.g., Prune dwarf virus [PDV] and Apple mosaic virus [ApMV]). In addition, bands were not observed with negative controls (water and preparations from healthy trees). An example of the results obtained with total nucleic acid preparations from a set of standard isolates of PNRSV, two PDV isolates, and an ApMV isolate is shown in Figure 1.

RT-PCR test on tissues from the PNRSV collections. For all 32 standard isolates tested (Table 1), the expected amplification product (348-bp) was observed. The RTPCR assay discriminated between PNRSVfree trees (10 trees) and PNRSV-infected trees (31 trees) in winter-sample bark tissues of orchard trees (Table 2). No amplification was observed for the negative controls (Tables 1 and 2).

Detection of PNRSV by real-time RTPCR. The amplification products observed in the total nucleic acid preparations from all the GF 305 peach twigs infected with the PNRSV isolates tested were detected with the MGB probe used (Table 1). An example of normalized fluorescence measurements obtained during the PCR amplification is shown in Figure 2. For the positive samples, detectable amplification was observed from or between cycles 19 and 26; no amplification was detected for the negative controls (Fig. 2).

Bark samples collected in winter from twigs of 41 orchard trees were tested for PNRSV by real-time RT-PCR. The 31 trees which gave positive signals by conventional RT-PCR also were positive by real-time RT-PCR. Products from tissue samples from trees 5, 11, and 17 were negative by conventional RT-PCR, but positive by real-time RT-PCR. Samples from seven trees (no. 4, 6, 7, 9, 13, 14, and 29) were negative when tested by both assays (Table 2). Negative controls were negative in both assays (Table 2).

Total nucleic acid preparations from 50 trees from the same orchards were tested in spring. Samples from 27 trees which tested positive by conventional RT-PCR also were positive by real-time RT-PCR (Table 3). Samples from 21 trees gave negative results for both detection systems. Tree 44 tested negative by real-time RT-PCR but a very faint signal was observed by conventional RT-PCR (Table 3). Tree 4 tested positive by real-time RT-PCR $(\mathrm{Ct}=38)$, but negative by conventional RT-PCR (Table 3).

Comparison of real-time detection of PNRSV from samples collected from the same trees in winter and spring. Of the seven trees that tested negative in winter, six also were negative in spring; thus, one tree was identified as a false negative in winter (Table 4). Of the 22 trees that tested negative in spring, 13 tested positive in winter (Table 4). These results were confirmed by RT-PCR assays (Tables 2 and 3 ). These 13 trees always tested negative in spring (Fig. 3), even when these real-time RT-PCR assays were extended to $50 \mathrm{cy}-$ cles.

\section{DISCUSSION}

PNRSV is a component of many phytosanitary certification programs of fruit trees. Viral concentrations of PNRSV are very low in bark tissues of fruit trees during dormant periods (22). These low viral titers may be undetectable by ELISA tests on bark collected during winter. ELISA then could be used only on bark samples collected in the spring (7). However, there is a need for the development of reliable, sensitive, and rapid tests allowing the detection of PNRSV from fruit trees during the dormant season. The real-time RT-PCR system described here allowed the detection of PNRSV from dormant bark tissues of plum and cherry trees.

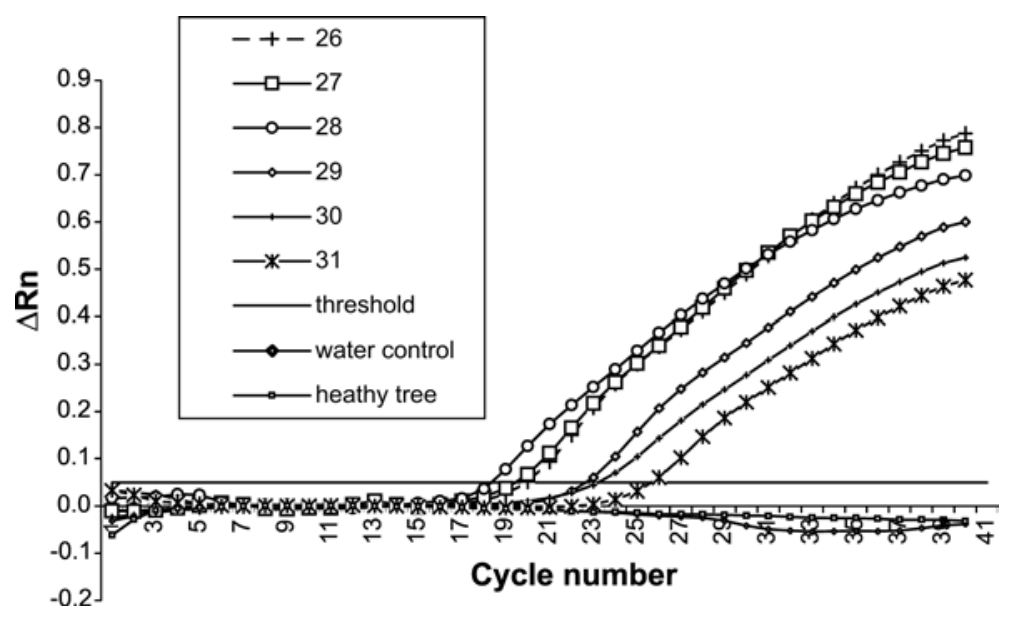

Fig. 2. Real-time detection of amplification products from the total nucleic acid preparations from the GF 305 peach twigs infected with the Prunus necrotic ringspot virus isolates 26, 27, 28, 29, 30, and 31. Amplification plot showing cycle number versus normalized fluorescence $(\Delta \mathrm{Rn})$. The horizontal line indicates the threshold. 
To our knowledge, this is the first report of the use of fluorogenic probes for the detection of PNRSV in fruit trees. To overcome the effect of the potential variability of the viral genome, a short fluorogenic hydrolysis probe (of approximately 12 to 17 nucleotides [nt]) conjugated to an MGB (12) was preferred to the usual TaqMan probes ( 24 to $40 \mathrm{nt}$ ). The covalent attachment of the MGB moiety stabilized the probe or target duplex and raised the melting temperature to a range suitable for $5^{\prime}$ nuclease assays. MGB probes have been used successfully to detect other highly variable viruses such as Apple chlorotic leaf spot virus (19) and Apple stem pitting virus (20) in apple trees.

To evaluate the efficiency of this assay, samples that had been tested previously by conventional RT-PCR were tested by realtime RT-PCR. The results obtained demonstrated that the real-time assay correlated with conventional analysis. The results of this real-time assay showed that out of 50 samples, 13 trees were identified as negative in spring but positive in winter. These results were confirmed by conventional RT-PCR.

PNRSV was detected by real-time RTPCR in total RNA preparations collected from three trees in winter and one tree in spring, whereas no bands were observed for the analysis of the same products by agarose gel electrophoresis. Thus, realtime RT-PCR appears to be more sensitive that conventional RT-PCR for the detection of PNRSV in total nucleic acid preparations.

The advantages of the real-time RT-PCR are as follows. Agarose gel electrophoresis is no longer required to confirm the presence of specific amplification products. This saves time and money and is less hazardous because ethidium bromide, a reported carcinogen, is not needed. Second, the single closed-tube format eliminates the need for post-PCR manipulations, greatly reducing the risk of false positive results due to carryover of PCR products. Third, when statistically significant amounts of fluorescence over background are detected, they are recorded as a $\mathrm{Ct}$ value. This makes the assay less subjective than visual comparison of DNA bands on a gel. This real-time RT-PCR assay then is suitable for routine analysis because it is simple, rapid, performed in a single test, and allows analysis of up to 96 samples at once in a standard format.

It should be noted that detection of amplified products by real-time RT-PCR requires expensive, special equipment and additional reagents compared with conventional gel-based detection. Also, for other variable viruses, the real-time RT-PCR test may fail to detect all virus isolates with a single specific probe.

To our knowledge, no information was available concerning the best time of the year to detect PNRSV in bark tissues of fruit trees. Our results showed that 1 tree was identified as false negative in winter and 13 trees were found to be false negative in spring. Thus, the real-time RT-PCR assay apparently appears more reliable for the detection of PNRSV in bark samples collected in winter than in spring. The

Table 3. Detection of Prunus necrotic ringspot virus from orchard trees in spring ${ }^{\mathrm{a}}$

\begin{tabular}{|c|c|c|c|}
\hline $\begin{array}{l}\text { Tree } \\
\text { number }\end{array}$ & Nature & Gel & $\begin{array}{c}\text { Threshold } \\
\text { cycle }\end{array}$ \\
\hline 1 & Cherry & 25 & + \\
\hline 2 & Cherry & 24 & + \\
\hline 3 & Cherry & ND & - \\
\hline 4 & Cherry & 38 & - \\
\hline 5 & Cherry & ND & - \\
\hline 6 & Cherry & ND & - \\
\hline 7 & Cherry & ND & - \\
\hline 8 & Cherry & ND & - \\
\hline 9 & Cherry & ND & - \\
\hline 10 & Cherry & 22 & + \\
\hline 11 & Cherry & ND & - \\
\hline 12 & Cherry & 26 & + \\
\hline 13 & Plum & ND & - \\
\hline 14 & Cherry & ND & - \\
\hline 15 & Cherry & ND & - \\
\hline 16 & Cherry & ND & - \\
\hline 17 & Plum & ND & - \\
\hline 18 & Plum & 35 & + \\
\hline 19 & Plum & 33 & + \\
\hline 20 & Cherry & 22 & + \\
\hline 21 & Cherry & 31 & + \\
\hline 22 & Cherry & 20 & + \\
\hline 23 & Cherry & 24 & + \\
\hline 24 & Cherry & 23 & + \\
\hline 25 & Cherry & ND & - \\
\hline 26 & Cherry & ND & - \\
\hline 27 & Cherry & 25 & + \\
\hline 28 & Cherry & 24 & + \\
\hline 29 & Cherry & ND & - \\
\hline 30 & Plum & 31 & + \\
\hline 31 & Cherry & ND & - \\
\hline 32 & Cherry & ND & - \\
\hline 33 & Cherry & 21 & + \\
\hline 34 & Cherry & 24 & + \\
\hline 35 & Cherry & 22 & + \\
\hline 36 & Cherry & 29 & + \\
\hline 37 & Cherry & ND & - \\
\hline 38 & Plum & 37 & + \\
\hline 39 & Cherry & 22 & + \\
\hline 40 & Cherry & 22 & + \\
\hline 41 & Plum & 28 & + \\
\hline 42 & Plum & 38 & + \\
\hline 43 & Plum & 29 & + \\
\hline 44 & Plum & ND & \pm \\
\hline 45 & Cherry & ND & - \\
\hline 46 & Cherry & 36 & + \\
\hline 47 & Cherry & 37 & + \\
\hline 48 & Cherry & ND & - \\
\hline 49 & Cherry & 36 & + \\
\hline 50 & Cherry & ND & - \\
\hline Water & $\ldots$ & ND & - \\
\hline Healthy & $\ldots$ & ND & - \\
\hline
\end{tabular}

${ }^{a}$ Detection by agarose gel electrophoresis and in real-time of amplified products corresponding to PNRSV isolates in total RNA extracts from infected trees. The table summarizes data from real-time detection and gel analysis; + and - indicate presence and absence of the expected band on gel respectively; \pm indicates faint signal with ambiguous detection on gel; NT = not tested; ND = not detected.

b Water $=$ water negative control and Healthy = healthy tree negative control. concentration of PNRSV in spring may be lower in the bark than in the other organs of the tree (i.e., in flowers, buds, and shoots). Nothing is known about variations in the PNRSV titers in the different organs of the fruit tree. Virus titer is just known to differ according to the host plant, the cultivar, and the seasons $(4,24)$.

Although PNRSV is systemically distributed in very susceptible plum cultivars and in peach (6), there are no reports that describe the distribution of PNRSV in cherry and plum trees. Consequently, we

Table 4. Detection in real-time of Prunus necrotic ringspot virus from orchard trees

\begin{tabular}{|c|c|c|c|}
\hline \multirow[b]{2}{*}{ Tree no. ${ }^{\mathbf{b}}$} & \multirow[b]{2}{*}{ Nature } & \multicolumn{2}{|c|}{ Threshold cycle $^{\mathrm{a}}$} \\
\hline & & Winter & Spring \\
\hline 1 & Cherry & 23 & 25 \\
\hline 2 & Cherry & 37 & 24 \\
\hline 3 & Cherry & 36 & ND \\
\hline 4 & Cherry & ND & 38 \\
\hline 5 & Cherry & 39 & ND \\
\hline 6 & Cherry & ND & ND \\
\hline 7 & Cherry & ND & ND \\
\hline 8 & Cherry & NT & ND \\
\hline 9 & Cherry & ND & ND \\
\hline 10 & Cherry & 20 & 22 \\
\hline 11 & Cherry & 36 & ND \\
\hline 12 & Cherry & 21 & 26 \\
\hline 13 & Plum & ND & ND \\
\hline 14 & Cherry & ND & ND \\
\hline 15 & Cherry & 39 & ND \\
\hline 16 & Cherry & 36 & ND \\
\hline 17 & Plum & 38 & ND \\
\hline 18 & Plum & 34 & 35 \\
\hline 19 & Plum & 33 & 33 \\
\hline 20 & Cherry & 21 & 22 \\
\hline 21 & Cherry & 19 & 31 \\
\hline 22 & Cherry & 20 & 20 \\
\hline 23 & Cherry & ND & 24 \\
\hline 24 & Cherry & 20 & 23 \\
\hline 25 & Cherry & 20 & ND \\
\hline 26 & Cherry & 37 & ND \\
\hline 27 & Cherry & 20 & 25 \\
\hline 28 & Cherry & 19 & 24 \\
\hline 29 & Cherry & ND & ND \\
\hline 30 & Plum & 31 & 31 \\
\hline 31 & Cherry & ND & ND \\
\hline 32 & Cherry & 20 & ND \\
\hline 33 & Cherry & 16 & 21 \\
\hline 34 & Cherry & 18 & 24 \\
\hline 35 & Cherry & NT & 22 \\
\hline 36 & Cherry & 16 & 29 \\
\hline 37 & Cherry & 33 & ND \\
\hline 38 & Plum & NT & 37 \\
\hline 39 & Cherry & 20 & 22 \\
\hline 40 & Cherry & 20 & 22 \\
\hline 41 & Plum & NT & 28 \\
\hline 42 & Plum & NT & 38 \\
\hline 43 & Plum & NT & 29 \\
\hline 44 & Plum & NT & ND \\
\hline 45 & Cherry & 37 & ND \\
\hline 46 & Cherry & 33 & 36 \\
\hline 47 & Cherry & 33 & 37 \\
\hline 48 & Cherry & 37 & ND \\
\hline 49 & Cherry & 37 & 36 \\
\hline 50 & Cherry & 37 & ND \\
\hline Water & $\ldots$ & ND & ND \\
\hline Healthy & $\ldots$ & ND & ND \\
\hline
\end{tabular}

${ }^{\text {a }}$ For samples in winter and spring: NT $=$ not tested and ND $=$ not detected.

${ }^{\mathrm{b}}$ Water $=$ water negative control and Healthy $=$ healthy tree negative control. 


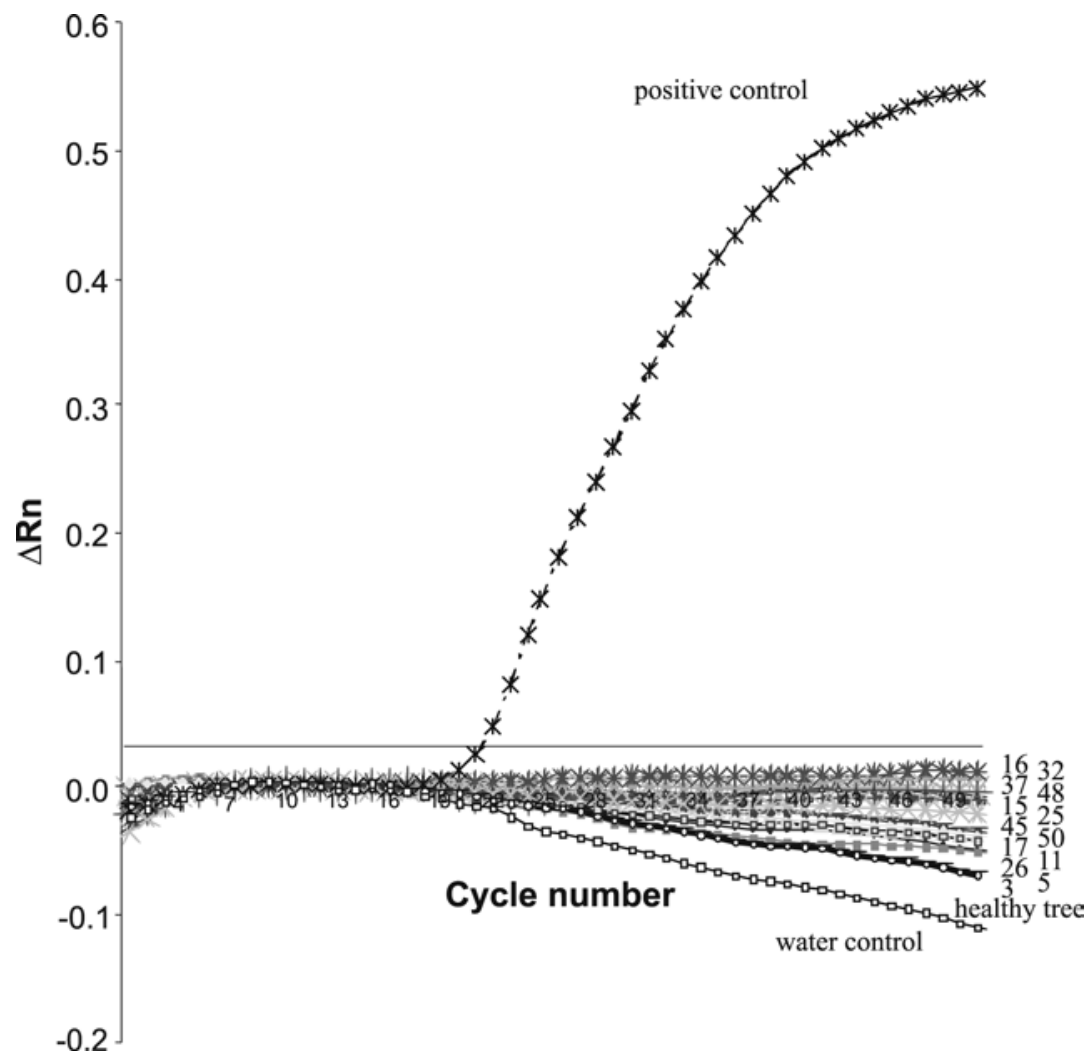

Fig. 3. Real-time detection of amplification products from the total nucleic acid preparations from the trees $3,5,11,15,16,17,25,26,32,37,45,48$, and 50. Amplification plot showing cycle number versus normalized fluorescence $(\Delta \mathrm{Rn})$. The horizontal line indicates the threshold. recommend here the need for testing multiple samples from different branches or time assay.

In conclusion, real-time RT-PCR provides a sensitive and high-throughput diagnostic assay particularly suitable for detection of PNRSV in dormant bark tissues and budwood of fruit trees. It could be used in routine analysis in diagnostic laboratories involved in certification programs of fruit trees.

\section{ACKNOWLEDGMENTS}

We thank T. Candresse, R. Guillem, and B. Pradier for kindly providing PNRSV-infected material; and A. Chandelier and $\mathrm{H}$. Jijakli for critically reading the manuscript.

1. Bustin, S. A. 2000. Absolute quantification of mRNA using real-time reverse transcription polymerase chain reaction assays. J. Mol. Endrocrinol. 25:169-193.

2. Clark, M. F., and Adams, A. N. 1977. Characteristics of the microplate method of enzymelinked immunosorbent assay for the detection of plant viruses. J. Gen. Virol. 34:475-483.

3. Crosslin, J. M., and Mink, G. 1992. Biophysical differences among Prunus necrotic ringspot Ilarviruses. Phytopathology 82:200-206.

4. Dal Zotto, A., and Nome, S. F. 1999. Fluctuations of Prunus necrotic ringspot virus (PNRSV) at various phenological stages in using pooled extracts for the sensitive real-

\section{LITERATURE CITED}

12. Kutyavin, I. V., Afonina, I. A., Mills, A Gorn, V. V., Lukhtanov, E. A., Belousov, E. S., Singer, M. J., Walburger, D. K., Lokhov, S. G., Gall, A. A., Dempcy, R., Reed, M. W, Meyer, R. B., and Hedgpeth, J. 2000. 3'-Minor groove binder-DNA probes increase sequence specificity at PCR extension temperature. Nucleic Acids Res. 28:655-661.

13. Lie, Y. S., and Petropoulos, C. J. 1998. Advances in quantitative PCR technology: $5^{\prime}$ nuclease assay. Curr. Opin. Biotechnol. 9:43-48.

14. Livak, K., Flood, S. J. A., Marmaro, J., Giusti, W., and Deetz, K. 1995. Oligonucleotides with fluorescent dyes at opposite ends provide a quenched probe system useful for detecting PCR product and nucleic acid hybridization. PCR Methods Appl. 4:357-362.

15. Livak, K., Marmaro, J., and Flood, S. 1996 Guidelines for designing TaqMan fluorogenic probes for $5^{\prime}$ nuclease assays. Perkin-Elmer Res. News 57:1-5. tor Res. 9:261-281.

17. Roberts, C. A., Dietzgen, R. G., Heelan, L. A., and Maclean, D. J. 2000. Real-time RT-PCR fluorescent detection of tomato spotted wilt virus. J. Virol. Methods 88:1-8.

18. Rosner, A., Malesnin, L., and Spiegel, S. 1997. The use of short and long PCR products for improved detection of Prunus necrotic ringspot virus in woody plants. J. Virol. Methods 67:135-141

19. Salmon, M., Vendrame, M., Kummert, J., and Lepoivre, P. 2002. Detection of Apple chlorotic leaf spot virus using a fluorogenic 3 minor groove binder-DNA probe. J. Virol. Methods 104:99-106.

20. Salmon, M., Vendrame, M., Kummert, J., and Lepoivre, P. 2002. Rapid and homogenous detection of Apple stem pitting virus by RT-PCR and a fluorogenic $3^{\prime}$ minor groove binderDNA probe. Eur. J. Plant. Pathol. 108:755762 .

5. Fulton, R. W. 1983. Ilarvirus group. C.M.I./A.A.B. Description of Plant Viruses, 260.

6. Grüntzig, M., Fuchs, E., Pfleistetter, E., Al Kai, B., and Otto, F. 1994. Untersuchungen zur Verleitung Mechanish Übertragbarer Viren in Bäumen des Kern-und Steinobstes. Arch. Phytopathol. Pflanzenschutz 29:217-248.

7. Helguera, P. R., Taborda, R., Docampo, D. M., and Ducasse, D. A. 2001. Immunocapture reverse transcription-polymerase chain reaction combined with nested PCR greatly increases the detection of Prunus necrotic ringspot virus in the peach. J. Virol. Methods 95:93-100.

8. Holland, P. M., Abramson, R. D., Watson, R., and Gelfand, D. H. 1991. Detection of specific polymerase chain reaction products by utilizing 5'-3' exonuclease activity of Thermus aquaticus DNA polymerase. Proc. Natl. Acad. Sci. USA 88:7276-7280.

9. Howell, W. E., and Mink, G. I. 1988. Natural spread of cherry rugose mosaic disease and two Prunus necrotic ringspot virus biotypes in a Central Washington sweet cherry orchard. Plant Dis. 72:636-640.

10. Korimbocus, J., Coates, D., Barker, I., and Boonham, N. 2002. Improved detection of Sugarcane yellow leaf virus using a real-time fluorescent (TaqMan) RT-PCR assay. J. Virol. Methods 103:109-120.

11. Kummert, J., Vendrame, M., Steyer, S., and Lepoivre, P. 2001. Development of routine RTPCR tests for certification of fruit tree multiplication material. Acta Hortic. 550:45-52.

21. Scott, S. W., Barnett, O. W., and Burrows, P. M. 1989. Incidence of Prunus necrotic ringspot virus in Selected Peach Orchards of South Carolina. Plant Dis. 73:913-916.

22. Spiegel, S., Scott, S. W., Bowman-Vance, V., Tam, Y., Galiakparov, N. N, and Rosner, A. 1996. Improved detection of Prunus necrotic ringspot virus by the polymerase chain reaction. Eur. J. Plant Pathol. 102:681-685.

23. Spiegel, S., Tam, T., Maslenin, L., Kolber, M., Nemeth, M., and Rosner, A. 1999. Typing Prunus necrotic ringspot virus isolates by serology and restriction endonuclease analysis of PCR products. Ann. Appl. Biol. 135:395400.

24. Torrance, L., and Dolby, C. A. 1984. Sampling conditions for reliable routine detection by enzyme-linked immunosorbent assay of three ilarviruses in fruit trees. Ann. Appl. Biol. 104:267-276.

25. Uyemoto, J. K., Asai, W. K., and Luhn, C. F. 1992. Ilarviruses: Evidence for rapid spread and effects on vegetative growth and fruit yields of peach trees. Plant Dis. 76:71-74.

26. Uyemoto, J. K., and Scott, S. 1992. Important diseases of Prunus caused by viruses and other graft-transmissible pathogens in California and South Carolina. Plant Dis. 76:5-11.

27. Weller, S. A., Elphinstone, J. G., Smith, N. C., and Stead, D. E. 2000. Detection of Ralstonia solanacearum from potato tissue by post-enrichment TaqMan PCR. OEPP/EPPO Bull 30:381-383.
16. Mink, 1992. Ilarvirus Vectors. Adv. Dis. Vec- 